\title{
Spiritual Communion in a Digital Age: A Roman Catholic Dilemma and Tradition
}

\author{
Edward Foley
}

Citation: Foley, Edward. 2021.

Spiritual Communion in a Digital Age: A Roman Catholic Dilemma and Tradition. Religions 12: 245. https:// doi.org/10.3390/rel12040245

Academic Editors: Terence Lovat and Simon S. M. Kwan

Received: 17 February 2021

Accepted: 24 March 2021

Published: 30 March 2021

Publisher's Note: MDPI stays neutral with regard to jurisdictional claims in published maps and institutional affiliations.

Copyright: (C) 2021 by the author. Licensee MDPI, Basel, Switzerland. This article is an open access article distributed under the terms and conditions of the Creative Commons Attribution (CC BY) license (https:// creativecommons.org/licenses/by/ $4.0 /)$.
Catholic Theological Union, Chicago, IL 60615, USA; foley@ctu.edu

\begin{abstract}
In the midst of this pandemic, most Christian Churches in the United States have been required to limit severely if not suspend face-to-face worship. The responses to this challenge when it comes to celebrating the Eucharist have been multiple. Frequent pastoral responses have included the shipping of consecrated elements to folk for their use during live-stream worship and virtual communion, in which worshippers employ elements from their own households as communion elements during the digitized worship. These options are not permitted for Roman Catholics. Instead, it is most common for Roman Catholics to be invited into spiritual communion. This is often considered a diminished, even ternary form of communing, quickly dispensed when quarantines are lifted and herd immunity achieved. On the other hand, there is a rich and thoughtful tradition about spiritual communion that recognizes it as an essential element in communion even when such is experienced face-to-face. This article intends to affirm the values of spiritual communion as a real, mystical and fruitful action that not only sustains people worshipping from afar, but enhances an authentic eucharistic spirituality.
\end{abstract}

Keywords: virtual communion; live-streamed worship; pandemic; liturgy; spiritual communion

\section{Introduction}

The COVID-19 pandemic has wrought havoc on innumerable aspects of life. From this author's context in the United States, notable examples of such disruption are apparent in our educational systems, small business ventures, new stresses on the underemployed, and profound challenges to age cohorts, economic classes, or communities of color that have confronted multiple health and heath care issues for decades. Institutionalized religions, like my own Roman Catholicism, have also faced unforeseen challenges. Traditional forms of community building with their multiple strategies for gathering the faithful have either been banned outright or seriously restricted. Expected and deeply honored forms of pastoral care such as visiting and anointing the sick, hearing confessions, or accompanying the dying have similarly been reduced and in many situations eliminated. Other sacramental expectations-confirmed in our Code of Canon Law (1983), which acknowledges that the baptized have a right to the sacraments (can. 213) - have been delayed or denied. These include baptisms, marriage rites and funeral liturgies. The widest impact has been experienced around the still obligatory and spiritually important practice of Sunday Mass. While all relevant studies acknowledge the decline in weekly Mass attendance by Roman Catholics (e.g., Gambino 2019), the desire for Sunday worship and its culminating act of receiving the consecrated elements in communion is yet strong and documentable.

In response, many parishes have turned to livestreaming Sunday worship through Facebook, YouTube, or other digital venues. There are yet to be any wide-ranging empirical studies on exactly how many congregations are capable of providing this service. Anecdotal information clearly points to congregations more urban, white and financially stable as typically capable and inclined to providing such services. Furthermore, at this early stage, we do have sufficient data to understand how this virtual move has sustained, increased, 
or decreased engagement among the faithful, much less good data about the quality of that engagement. At one parish in which I preside and preach, the pre-COVID-19 practice of live streaming the 5:00 p.m. Mass on Sunday afternoon would draw around 300 hits (Old St. Patrick's Church n.d., 4667723). The first Sunday during the shuttering of churches, admittedly adjacent to its highly touted patronal feast day, the parish combined its St. Patrick's celebration with its first livestreamed 10:00 a.m. Mass, garnering 36,502 viewers (Old St. Patrick's Church n.d., 9038563).

While a preliminary analysis of such anecdotal information suggests that the digital availability of Sunday and even weekday Mass is of great value to many, it also triggers a particular dilemma. A theological as well as experiential highpoint of the Mass for many Roman Catholics is reception of communion, especially the bread. A hallmark of the 20th century liturgical reforms was the promotion of more frequent communion among the faithful. This began with the reforms of Pius X (d. 1914), who lowered the age requirement for communion from 12 to 7 years of age (Quam Singulari, Pius X 1910). It continued through the reforms of Pius XII (d. 1958), who twice modified the fasting requirements before communion (Christus Dominus, Pius XII 1953 and Sacram Communionem, Pius XII 1957). This eucharistic promotion culminated in Vatican II's 1963 decree on the liturgy, which considers the faithful's reception of the eucharist the "more perfect form of participation in the Mass" (Second Vatican Council 1963, no. 55).

The reasons why this physical receiving is so highly prized are rich and multiple. They are rooted in the mystery of the incarnation, in which the Godhead was intimately wed to creation through the birth of the Only Begotten. Jesus' own ministry displayed an intimate engagement with flesh and blood folk and the stuff of creation. His table ministry, culminating in the Last Supper, was not an invitation into some kind of gnostic experience but the embodied practice of eating and drinking. This tangible and public act was a continued source of critique and condemnation by his opponents (e.g., Mark 2:16; Matt 9:10; Luke 5:30). According to Henri de Lubac, the table was also the birthplace of the church as, "literally speaking ... the Eucharist makes the Church" (de Lubac 2006, p. 88). Later theological developments will distinguish this eucharistic presence from other modes of Christ's presence-e.g., in the Word-as a "substantial" presence. Thus, this mode of presence surpasses all others because "through it Christ becomes present whole and entire, God and Man" (Paul VI 1965, no. 39).

Thus, the dilemma: the reception of communion has evolved as a pastoral and theological high point of participation for Roman Catholics at Mass. This is distinct from medieval and post-Tridentine evidence that points to the elevation of the Host after the consecration as the high point. ${ }^{1}$ However, the pandemic with its many closures and restrictions has eliminated communion for multitudes of Roman Catholics. While livestreaming the eucharistic liturgy clearly feeds people's spiritualities, it falls short of meeting this need for eucharistic reception.

\section{Eucharistic Deprivation and Abstinence: An Historical Perspective}

In one sense, the pandemic currently sweeping across the globe and enveloping Christianity in its wake (and thus Roman Catholicism) has created a unique dilemma. Yet, it has some historical precedents. There is clear evidence in the history of Christianity that in different times and places significant numbers of the baptized have been deprived of the eucharist, sometimes because of their own sense of unworthiness. The celebrated bishop and mystagogue John Chrysostom (d. 407) preached powerfully against anyone who was unworthy who dared to receive communion. Not only does he warn against the baptized receiving "this Body into an evil soul", but also cautions clergy against admitting anyone to communion who is known to be unworthy. Both baptized and clergy who engage in such worthiness are, in Chrysostom's estimation, the same as the betrayer Judas (Chrysostom

1 Eamon Duffy summarizes this evolution by noting that by this point "for most of the people, most of the time the Host was something to be seen, not to be consumed" (Duffy 2005, p. 95). 
1986, 82:6). At the same time Chrysostom complained that some folk limited their reception to major feast days, lamenting that even though the "sacrifice is offered", yet no one comes forth for communion (Chrysostom 2002, 3:4).

Multiple factors led to this eventually wide-spread practice of communal and individual withdrawal from the table. One significant element was an evolving self-awareness of the laity that inverted from viewing themselves as the body of Christ to a deeply diminished self-image as a community of sinners and penitents. A burgeoning theology of original sin and the prominent specter of purgatory in the imaginations of the faithful loomed large in this development. While Chrysostom was a voice from the early church that raised concern about declining numbers of communicants, that trend developed so dramatically that the Fourth Lateran Council (1215) had to mandate that people go to communion at least once a year (Mansi 1901-1927, no. 21, 22:1010). Despite this directive the communion of the faithful remained an infrequent event for many baptized. Those belonging to religious communities often needed the permission of their superior or spiritual director to receive, regularly restricted to four or six times a year. In the 17th century the movement known as Jansenism, which strongly emphasized the depravity and corruption of human beings, responded by valuing abstinence from communion and upheld it as a mark of holiness equal to that of actual reception (Mitchell 2009, p. 463).

The so call "plague of Saint Charles" that struck the region of Lombardy from 157576, particularly its capital Milan, is an informative episode in this history of eucharistic deprivation. According to his biographer, Milan's Archbishop Charles Borromeo threw himself into the midst of this epidemic, providing both material and spiritual relief to his people (Giussano 1884, pp. 367ff). He not only went among his people distributing communion, but "he directed that every one should hear Mass devoutly each day; and to give effect to this order, he erected altars at the crossways and conspicuous places, where Mass was said daily, so that all could assist from their windows" (Giussano 1884, p. 419). His biographer makes no mention of spiritual communion regarding this (or any other) event, and Borromeo gives scant attention to the topic in his writings. Nonetheless, this unique example of virtual eucharist certainly provided that opportunity for its home-bound participants.

A different sort of eucharistic deprivation became prominent in the so-called age of discovery, when sea-faring European adventurers set out to explore the globe and claim new territories. Roman Catholic missionaries such as the Franciscans and Dominicans ordinarily accompanied Portuguese and Spanish explorers, a trend that both continued and expanded in ensuing centuries. Thus, Stephen Bevans (2002) summarizes: "The modern missionary era was in many ways the 'religious arm' of colonialism, whether Portuguese and Spanish colonialism in the sixteenth Century, or British, French, German, Belgian or American colonialism in the nineteenth". While many missionaries established churches and even compounds in colonial settles, they often ventured beyond those sites to seek converts. This sometimes involved establishing ties with remote villages or outposts that could be revisited to sustain believers. Such visits were generally few and far between. One documentable example in the United States was Fr. Pierre Yeves Kéralum OMI (d. 1872). He was a member of the "Calvary of Christ", a group of Oblate clergy who traveled by horseback throughout the Rio Grande area ministering to far flung Catholics at their ranches and settlements. Three times a year he would make a missionary circuit to some 70 to 120 places spread over a vast territory in the Texas wilderness (Wright n.d.). Between such visits the Catholic families would naturally be deprived Eucharist until the next circuit. This continues to be the situation in many places. My own Capuchin community's ministry in Nicaragua requires our friars to travel by boat or horseback in order to stay in touch with communities they can sometimes visit only once a year.

In the 20th century radio and eventually television emerged as new pastoral tools for reaching believers incapable of being physically present for Mass. One of the earliest examples occurred in Australia when Sydney was chosen as the site for the 1928 Eucharistic Congress. Catholic organizers of the Congress considered it a prime moment for evange- 
lization at a time when over $95 \%$ of the Australian population was Christian and almost $25 \%$ Roman Catholic (Australian Bureau of Statistics 1921). Consequently, Catholic leadership rented time on the newly established radio station 2UE, first broadcasting special services from Sydney's St. Mary's Cathedral leading up to a live broadcast of the Congress' opening Mass (Griffen-Foley 2008, p. 34).

In the late 1940's Roman Catholic Mass was first broadcast on television, initially on Christmas eve from Paris' Notre Dame Cathedral in 1948. The following year the Christmas Midnight Mass was televised from Boston's Cathedral of the Holy Cross. Such moves were not without controversy. The celebrated German theologian Karl Rahner (d. 1984) strongly objected to televised Mass, arguing that "philistines of the 21st century" should not be allowed to view whatever they wanted while "sitting in an armchair and ... chewing a roll" (Rahner 1953, pp. 182-83). Despite such objections, the number of televised Masses grew rapidly. Already in 1955, the Archdiocese of Boston inaugurated the CatholicTV Network: its first program was a Mass celebrated by the archbishop. This service continues yet today. As such productions multiplied, they were increasingly billed as Masses for "Shut-ins". This evolution acknowledged another group of folks regularly deprived of the Eucharist: the sick or the elder unable to regularly fulfill their Sunday obligation. A Canadian version of "Mass for Shut-ins", first appearing in 1963, is one of the longest running shows in that country's television history (MacDonald 2020). The practice is so widespread in the United States that in 1996 the United States Catholic Conference of Bishops published "Guidelines for Televising the Liturgy" (USCCB 1996).

\section{Spiritual Communion as a Roman Catholic Pastoral Response}

Obviously, Roman Catholicism is not the only church confronted with this unexpected stricture on the eucharistic table. Most Christian communities are facing this predicament and have mustered a wide range of responses. Some communities have begun the practice of delivering individual packages of consecrated bread and wine to congregants so that they could receive communion during a live streamed broadcast of the church's Sunday worship (Millard and Paulsen 2020). Related is the emerging practice of "drive-thru communion", in which pre-packaged Communion elements are given to folk through their car window, often in the parking lot of an established church (Pine Castle United Methodist Church n.d.). I know of some Roman Catholic communities that provide drive-thru communion following Sunday morning Mass, which draws a larger number of participants that current guidelines allow for face-to-face worship. A more inventive solution has been mailing consecrated elements to folk through via post, particularly in the United States and England. While bishops of some denominations have authorized this activity, others have severely criticized it (Williams 2020).

One of the more widespread and controverted practices is some form of "virtual communion", in which believers assemble appropriate elements from their own households (e.g., crackers or bread and wine or grape juice) and employ them for communion at the appropriate time in the live streamed or replayed rite. This is not a new practice. California's mega-church Saddleback in the Baptist tradition has provided guidelines for this kind of virtual communion since 2014 (Saddleback Church 2014). However, since the onset of the COVID-19 pandemic and the shuttering of churches, this practice has escalated dramatically while igniting widespread debate: often within a single denomination. Internet postings confirm that individual Anglican, Episcopal, Lutheran, Methodist, Presbyterian as well as Evangelical congregations are engaged in this practice.

While multiple denominations have found viable modes for communion in virtual worship, current Roman Catholic magisterial teaching does not recognize the validity of virtual sacraments. The most explicit example of such teaching during the COVID-19 pandemic is a note from the Apostolic Penitentiary (2020) on the Sacrament of Reconciliation, which instructs that even in this pandemic that sacrament is administered in according with universal canon law, i.e., person to person. Previously, the Pontifical Council for Social Communications (2002) emphasized the essential nature of such a "real interpersonal 
community" as well as "the incarnational reality of the sacraments" (no. 5). It concludes, "Virtual reality is no substitute for the Real Presence of Christ in the Eucharist, the sacramental reality of the other sacraments and shared worship in a flesh-and-blood human community. There are no sacraments on the Internet" (no. 9). Besides the clear prohibition against "virtual communion", this author cannot find any pastoral directives permitting the shipping of consecrated hosts to congregants or dropping them off at homes of the faithful for consumption during live-streamed worship. Such practices fall outside the directives for "Holy Communion outside Mass" found in the 1973 decree by the Sacred Congregation for Divine Worship (1976) "Eucharistic Worship outside Mass". Those directives make it clear that such communion requires an ordinary or extraordinary minister of communion (no. 20). At the same time, these official instructions do not ensure that such practices are absent in Roman Catholic communities.

More accepted and widespread in my tradition is the invitation for on-line worshippers to engage in the practice of spiritual communion at the appropriate time in the rite. Pope Francis has advocated this practice, and on more than one occasion has led the faithful on-line in a traditional prayer for spiritual communion, e.g., on 21 March 2020 using that of Alphonsus Liguori (Mares 2020). Despite this papal example, to some this might yet appear to be a quite inadequate substitute for the "real thing", a kind of pseudo-sacrament in which the priest does not take part because he always gets to receive physical communion. The history and theology of this previously revered practice, however, is infinitely richer and offers a valuable spiritual pathway for believers, and not only in time of pandemic.

A distinction between receiving the eucharistic bread sacramentally and receiving it spiritually stretches all the way back to Augustine (d. 430). In his Tractates on the Gospel of John (Augustine 1988, 26:11-12) the bishop of Hippo instructs the baptized to eat not only on the outside, with one's teeth, but also feast on the inside in one's heart. This is eating the heavenly bread in a spiritual sense. It is not until the Middle Ages, however, that a more developed theology of spiritual communion evolves. In its origins this "mystical approach to the Eucharist", as Gary Macy calls it, was a corrective to a theology of the Eucharist rooted in the teachings of Paschasius Radbertus (1969, d. 865). In Paschasius' pioneering work on the nature of eucharistic presence, De Corpore et Sanguine Domini, this 9th century monk was the first theologian to attempt explaining in a systematic and doctrinal way "how" Christ was eucharistically present. In his explanation, Paschasius proposed that the relationship between the historical body and the eucharistic body of Christ was one of identity, not merely continuity (4:1). While understanding that this presence was not just corporeal but also spiritual and mystical, his language and frameworks were insufficient to negotiate these nuances and the fundamental explanation was prone to collapse into physicality. While rejected by theologians such as Thomas Aquinas (d. 1274) and ultimately by the Church's magisterium that took a more metaphysical and sacramental approach, Paschasius' approach was easily and deeply embraced by the faithful and many theologians. In essence, Paschasius taught when we received communion we feasted on the same flesh of Jesus born of Mary, though offered gently and humanely through bread which served as a kind of visual envelope for the Lord's corporeal presence.

It was in response to this inventive yet crude explanation of Christ's eucharistic presence that the more mystical approach emerged. Early formulations distinguished between the sacrament the faithful receive on earth and the heavenly bread on which the angels feed. Although all who receive eucharistic bread on earth do receive the "true" body and blood of Christ, it is only the good who receive the bread of heaven by which one is joined to Christ in faith and love (Macy 1984, p. 76). This soteriological argument rejected any Paschasian claim that feasting on the body of Christ alone was sufficient for salvation: a stance based on a passage in a letter Paschasius wrote to Fredugard, a fellow monk of St-Riquier Monastery. Instead, it (re-) introduced the role of virtue, integrity and spiritual union into the equation of effective and grace-filled communion reception.

Though overshadowed by theologians of the 13th century, Hugh of Saint-Victor (d. 1141) crafted a profound and influential theology of eucharist in this mystical tradition. 
The abbey of Saint-Victor near Paris followed the Augustinian rule, and Hugh imbibed the Augustinian synthesis that emphasized the union of heaven and earth and the union of the baptized with each other that the eucharist both symbolized and enabled. Gary Macy has well summarized the various strands of Hugh's teaching on the issue of communion and its relationship to salvation (Macy 1984, pp. 83-85). Hugh and those of his school held that the whole of salvation history moves towards spiritual union with Christ. Through the working of the Holy spirit, by the sacraments - especially baptism and Eucharist-people experience the graces of faith and love that lead to this union. According to Hugh, the physical presence of the historical Jesus leads us through his outward appearance to his spiritual existence and, therefore, leads to our mystical union with Christ in faith and love. The eucharist does the same through the use of bread and wine. As Macy summarizes, "this spiritual union in faith and love, toward which all salvation history tends, is by far the most important aspect of the Eucharist for Hugh. To receive the sacrament worthily one must receive in faith and love. Further, if one cannot receive the outward sign of the Eucharist, faith and love alone are sufficient to gain the spiritual union with Christ" (Macy 1984, p. 83).

Other medieval theologians emphasized the centrality of this spiritual reality in their own eucharistic theologies. Some distinguished between reception corporaliter and reception spirtualiter. This distinction further counters the Paschasian view that weds salvation to the physical consuming of the eucharistized bread. Instead, it emphasizes that simply consuming the bread does not lead one to salvation. It is only by imitating Christ in faith and love and thus participating in the spiritual reception as well does one follow the salvific path (Macy 1984, p. 84). Some authors held that spiritual reception does not require the physical consumption of the sacrament. Apparently, Hugh of St. Victor's own "spiritual communion" on his death bed without sacramental reception-witnessed by the monk Osbert of Clare who later reported it in his correspondence (Macy 1984, p. 95)—confirms the theologian's deep convictions about the primacy of this spiritual union.

Famous mystics of the same period, often through deeply intimate reflections, attested to the efficacy of this form of spiritual union. One of more celebrated examples is that of Mechtild of Magdeburg (Mechtild of Magdeburg 1998, d. about 1282). Her extensive writings document both her deep eucharistic devotion and belief in the power of spiritual communion as well. She was part of a religious movement of women in the 12th and 13th centuries who lived a form of lay religious life in the world. One of the marks of this movement was their practice of receiving communion very frequently, i.e., weekly and sometimes even daily for which they "practically waged war against their confessors and superiors to attain permission" (Macy 1984, p. 90). Despite this increased frequency, Mechtild yet pens a spiritual complaint turned revelation "that she hears no Mass nor Hours and How God Praises her in ten things".

I who am Divine am truly in you.

I can never be sundered from you:

However far we be parted,

never can we be separated.

I am in you and you are in Me.

We could not be any closer.

We two are fused into one,

poured into a single mould.

Thus, unwearied,

we shall remain

forever.

(Mechtild, p. 111) 
This intense expression of mystical communion epitomizes a trend in which spiritual communion was theologically affirmed, pastorally promoted and personally cherished.

The insertion of the elevation of the bread into the eucharistic liturgy, already in some places by the end of the 12th century, provided a new opportunity for practicing spiritual communion during the Mass. One caution, however, is that we do not have clear evidence when exactly people engaged in this practice. Works like the 13th century Ancrene Wisse (Hasenfrantz 2000) note that "salutations" were to be recited during the elevation (e.g., "Hail, provision on our pilgrimage"). Some of these were repeated in the 14th century The Lay Folks Mass Book. (Simons [1879] 2008) There is a difference between "adoration" and "spiritual communion". The saluting of the host was clearly an act of adoration. It is not clear, however, how often such engagement was intentional spiritual communion properly understood. The same could also be said about the opportunities offered by the burgeoning practice of eucharistic processions.

The virtuous instincts of Hugh of St. Victor for connecting the act of physical reception of communion with the proper spiritual disposition affirmed by an integrity that expressed itself in a faith manifest in love was often overlooked in the ensuing centuries. Some theologians and clergy were concerned that frequent communion could breed indifference to the sacrament. Consequently, preachers often emphasized that spiritual communion brought all of the benefits but none of the risks of actual communion. Dutch theologian Wessel Gansfort (d. 1489) "went so far to argue that spiritual communion was superior to sacramental communion because it was not restricted to specific times, places or persons" (Burnett 2011, p. 84). This extreme view found resonance in the influential teaching and practices of the monastery of Port-Royal in Paris. Aligned with the teachings of Jansenism that emphasized the basic depravity and corruption of all people, the abbess Mere Angélique Arnauld (d. 1661) promoted voluntary abstinence from Communion, claiming that such could be a mark of holiness equal to that of actual reception (Mitchell 2009, p. 463).

\section{Healing the Rift}

The theological views of Gansfort, Arnauld and others as well as the practices they promoted created an unwelcome divide between reception corporaliter and reception spiritualiter. Hugh of St. Victor and others of his school understood spiritual reception as an essential part of the physical act of receiving communion worthily. Contrary to a strand of teaching found in the work of Paschasius and his many followers, they taught that consuming the host was insufficient for the heavenly union that the sacrament symbolizes. Instead, intention and desire wed to a life of faith and love were the paths that properly opened the graces of communion. Rather than viewing reception corporaliter and spiritualiter as both complementary and intrinsically related, however, in practice these became separated realities: the first reserved for the worthy and shriven and the second relegated to the undeserving who avoided physical reception and its threat of damnation if received unworthily. Consequently, even in the present day of frequent communion by Roman Catholics this mystical and deeply spiritual aspect of reception is widely underplayed. Thus, the connection between receiving communion and living a eucharistic life has receded from the consciousness of many a communicant. In this environment, rather than an essential component of eucharistic integrity, spiritual communion can appear to be a pious, vaguely wistful yet ultimately unfulfilling exercise in the absence of "real" reception.

While the COVID-19 pandemic has been an appalling experience on so many levels, that does not preclude it as a context for wisdom both ancient and new. The invitation to spiritual communion-sundered from physical reception for so many who regularly live-stream Mass during this health crisis-is yet an opportunity for catechizing folk about the sacramental reality of desire, the truth of mystical communion, and the multiple modes of Christ's real presence that the Roman Catholic Church acknowledges. As to the former, Christians from the time of Augustine (d. 430) to the present day have affirmed that authentically desiring baptism when it is not physically possible to undergo the ritual is 
true baptism. In his writings against the Donatists, Augustine holds that baptism can occur through suffering but also by "conversion of heart" (Augustine 1887, 4:22) or what came to be known as baptism of desire. The validity of such baptism was reiterated by Thomas Aquinas (d. 1274) in his Summa Theologica (e.g., Aquinas 1947, III, q. 68, art. 2), upheld by Alphonsus Liguori (de Liguori 1852, Bk 6, II, 1, 96), confirmed in the Catechism of Pius $X(2015$, p. 65), and is further recognized by the current Catechism of the Catholic Church (1992, no. 1258).

Similarly, mystics and theologians have affirmed in their teachings and personal practices that desiring Eucharist is not simply a pious exercise but also a doctrinally affirmed, real encounter with the eucharistic Christ (Costa 2012, p. 139). Aquinas himself argues that while it is not equal to the full experience of sacramental communion, spiritual communion-or communion in voto-is nonetheless an effective and grace filled activity (Aquinas 1947, III, q. 80, a. 1, ad 3). In two different sessions, the Council of Trent also recognized the validity and importance of spiritual Communion (Session 13, chp. 8; Session 22, chp. 6). In other words, spiritual communion is "real" communion, although not as perfect as physical reception. Due to the Roman Catholic insistence on Christ's real presence in the consecrated species, "real presence" has been a phrase unfortunately confined to the eucharistized elements. However, the Constitution on the Sacred Liturgy from Vatican II-largely drawing on the teaching of Pius XII's encyclical Mediator Dei (1947) - authoritatively taught that Christ is present in five different ways: (1) in the person of the minster, (2) under the eucharistic species, (3) in the sacraments, (4) in the Word, and (5) in the assembly (Second Vatican Council 1963, no. 7). This is a teaching yet to settle deeply into the spiritualities of most Roman Catholics, who are inclined to posit "real presence" only of the consecrated elements. The other 4 modes of that presence are perceived - if at all—as shadows of the one "true" presence under the appearances of bread and wine.

The Christological reality, however, is that Christ never promises to be partially present. Thus, Christ's presence in the proclamation of the gospel is not a $60 \%$ rendering of the presence of the eternal Logos. Nor is the assembly some tarnished reflection of the Body of Christ. On the contrary, long before there were tabernacles or reserved sacraments or eucharistic devotion, Paul was asserting that the community is the Body of Christ (1 Cor. 12:27). This expansive Christological rethinking find its most jarring expression in the often-overlooked assertion of Christ's presence in the sacraments, i.e., when anyone baptizes "it is really Christ who baptizes" (Second Vatican Council 1963, no. 7). This means that when a Jewish or Muslim nurse working in a neonatal unit, surrounded by days old infants, discerns that one of the newborns identified as "Catholic" is in danger of death and then baptizes, Christ is present: this despite the fact that there may not be a single Christian in the room.

Real presence in this expansive sense is a recovered yet often unexplored gift of conciliar and post-conciliar theology. When quarantined folk join a live-streamed eucharist and listen to the Word proclaimed, they experience the true presence of Christ. The power of God's Word does not evaporate over the Internet. Similarly, digital broadcasts do not impede experiencing presiders or even other baptized as they populate a zoom or Facebook worship space as authentic encounters with the Lord's presence. Different-definitely! Inauthentic - no! Therefore, too, communing spiritually with the presider through televised Mass is true communing, albeit not its fullest expression.

Advances in media theory and theological reflections on emerging understandings of issues such as virtual presence and digital communities bolster this position. Already in 1998, the Roman Catholic theologian Tom Beaudoin was exploring video games, MTV videos, music and cyberspace as venues where generation $\mathrm{X}$ was forging its own theologies. In Beaudoin's language, this allowed alternative ways of being virtually religious, and even engaging in virtual liturgy. In a visionary way, Beaudoin recognized that "cyberspace" held the potential for virtual communities where virtual religion could be practiced (Beaudoin 1998, pp. 37-49). With the expansion of the world wide web, especially in the early 21st cen- 
tury, theorizing about virtual presence, online religion and digital communities blossomed. Margaret Wertheim was a pioneering voice, arguing that the very essence of cyberspace is its capacity to service as a network of relationships and a technologically realized new heaven (Wertheim 1999, esp. 120-54). In shaping methodologies for studying religion in cyberspace Christopher Helland proposed a widely employed distinction between online religion and religion online. The former characterizes websites that encourage the interactivity of web users, while the latter were more content driven with little or no possibilities for interaction (Helland 2000). It was the former, he argued, that were important for the shaping of community. While this binary framework has been criticized for its lack of porosity (Young 2004), it nonetheless shows the continuing quest for discovering how cyberspace supports and encourages communitas. Similarly, non-religious works dating back to Howard Rheingold's ([1993] 2000) The Virtual Community, have argued for both the real possibility and definite value of this digital fellowship while also recognizing its limitations and shadow sides.

The contributions from media theory take a particular turn and confront questions they cannot answer alone, however, when it comes to sacramental worship. As Heidi Campbell recognizes, it is one thing to speak about the internet as a medium for facilitating spiritual experiences, or a tool for promoting religion, or as a technology for affirming the religious life and traditions of a community. It is another to consider it a "sacramental space" (Campbell 2005, p. 11). This has particular ramifications for Roman Catholic eucharistic theology, which is not always properly understood by contemporary commentators on virtual worship. ${ }^{2}$ Teresa Berger, the Thomas E. Golden Professor of Catholic Theology at Yale, provides a useful context for pondering such questions by underscoring that Christian worship itself has always been "mediated", and that digital technologies stand in a long line of liturgical mediations (Berger 2018, pp. 7-8). She also smartly recognizes that digitally mediated worship is not disembodied but entails its own specific bodily proprieties (Berger 2018, p. 20). Finally, she illustrates that an ecclesial community beyond spatial proximity is possible and that Church cannot be simply defined by the physical co-presence of believers (Berger 2018, p. 44). On the other hand, Berger acknowledges that the most challenging issuing here concerns questions of sacramental practices in digital mediation (Berger 2018, p. 75). When it comes to eucharist she does not advocate for digitally mediated eucharistic sharing (Berger 2018, p. 96). She does recognize, however, that our rich traditional of sacramentality provides a context for recognizing virtual eucharist as broadly "sacramental". This is not, however, the same as receiving the consecrated elements that Roman Catholics believe mediate a unique and substantial presence of Christ (see Labenek 2014, esp. 42-50). Thus, spiritual communion as a digitally mediated encounter, in the context of an on-line ecclesial event, framed by Christ's presence in the Word, is rightly understood as a sacramental exercise- though not properly understood as a sacrament. Paradoxically, physically receiving communion is itself an experience of presence and absence (Parish 2020), i.e., an absence of the historical body of Christ, one of the three bodies of Christ recognizes by ancient church teaching

\section{Conclusions}

Nathan Mitchell has insightfully recognized that the emergence of sacraments of desire, including spiritual communion, were valid attempts to broaden access to sacraments "without denying the legitimacy or necessity of the Church's liturgical celebrations" (Mitchell 2009, p. 463). One could argue in that same vein that eucharistic forays into the media - be that radio, television, or the Internet—are valid contemporary endeavors for achieving that same access while simultaneously affirming the central import of that key ecclesial ritual, Sunday Mass.

2 Daniel Bare, for examples, misunderstands the Roman Catholic teaching about transubstantiation as he contends "The Roman Catholic Church holds that the bread and wine transubstantiate, that their substance is transformed into the literal, physical body and blood of Christ." (Bare 2020, 37) Bare fails to recognize that substance is a metaphysical not physical construct, and cannot be changed into the physical body and blood of Christ. The Roman Catholic Church holds for a true, real and substantial presence but one present in a sacramental and not physical mode. 
Spiritual communion has reemerged in Roman Catholic consciousness as an appropriate, even necessary form of the active participation mandated by the Constitution on the Sacred Liturgy (no. 14). Unfortunately, this under catechized and little theologized practice yet suffers under the veil of a kind of sour grapes spirituality, i.e., it is the best we can do, although it leaves a bad taste in our mouths. While I long for the return to a nave overflowing with the baptized, full throated singing without masks, and communion lines replete with "Amens" that echo after each moment of sharing bread and cup, I also long for a renewed commitment to spiritual communion. This is a yearning for a deep consciousness among communicants-including the clergy - that authentic reception is not simply corporaliter but also spiritualiter. It is only in reuniting these too often severed perspectives that we can fulfill Augustine's challenge, and become what we eat (Augustine 1997, Sermon 272).

Funding: This research received no external funding.

Institutional Review Board Statement: Not applicable.

Informed Consent Statement: Not applicable.

Conflicts of Interest: The author declares no conflict of interest.

\section{References}

Apostolic Penitentiary. 2020. Note from the Apostolic Penitentiary on the Sacrament of Reconciliation in the Current Pandemic. March 20. Available online: https:/ press.vatican.va/content/salastampa/en/bollettino/pubblico/2020/03/20/200320d.html (accessed on 8 March 2021).

Aquinas, Thomas. 1947. The Summa Theologia. Translated by Fathers of the English Dominican Province. New York: Benziger Brothers. Augustine. 1887. Baptism, Against the Donatists. Translated by J. R. King. New York: Charles Scribner's Sons.

Augustine. 1988. Tractates on the Gospel of John 11-27. The Fathers of the Church, 79. Translated by John Rettig. Washington, DC: Catholic University of America Press.

Augustine. 1997. "Sermon 272". Trans. Nathan Mitchell. Assembly 23: 14.

Australian Bureau of Statistics. 1921. Census of the Commonwealth of Australia. Available online: https:/ /www.ausstats.abs.gov. au/ausstats/free.nsf/0/F71203E9C651751CCA2578390015AB47/\$File/1921\%20Census\%20-\%20Volume\%20I\%20-\%20Part\% 20VI\%20Religions.pdf (accessed on 8 March 2021).

Bare, Daniel. 2020. How Embodied is 'the Body of Christ?' COVID-19 and Christian Corporeality. In Religion in Quarantine: The Future of Religion in a Post-Pandemic World. Edited by Heidi Campell. pp. 36-38. Available online: https:/ / oaktrust.library.tamu.edu/ bitstream/handle/1969.1/188004/Religion\%20in\%20Quarantine-PDF-eBook-final-2020.pdf?sequence=4\&isAllowed=y (accessed on 8 March 2021).

Beaudoin, Tom. 1998. Virtual Faith: The Irreverent Spiritual Question of Generation X. San Francisco: Jossey-Bass.

Berger, Teresa. 2018. @ Worship: Liturgical Practices in Digital Worlds. New York: Routledge.

Bevans, Stephen. 2002. New Evangelical Vision and Mission. Divine Word Missionary Magazine.

Burnett, Amy Nelson. 2011. The Social History of communion and the Reformation of the Eucharist. Past \& Present 211: 77-119.

Campbell, Heidi. 2005. Spiritualising the internet. Uncovering discourses and narratives of religious internet usage. Online. Heidelberg Journal of Religions on the Internet 1: 1-26.

Catechism of the Catholic Church. 1992. Available online: https:/ /www.vatican.va/archive/ENG0015/_INDEX.HTM (accessed on 8 March 2021).

Chrysostom, John. 1986. Homilies on the Gospel of St. Matthew, Rev. ed. Nicene and Post-Nicene Fathers. Translated by George Prevost. Grand Rapids: Eerdmans, vol. 10.

Chrysostom, John. 2002. Homilies on Galatians, Ephesians, Philippians, Colossians, Thessalonians, Timothy, Titus, and Philemon. Nicene and Post-Nicene Fathers. Grand Rapids: Eerdmans, vol. 13.

Code of Canon Law. 1983. Available online: http://www.vatican.va/archive/cod-iuris-canonici/cic_index_en.html (accessed on 8 March 2021).

Costa, Francis. 2012. Nature and Effects of Spiritual Communion. Proceedings of the Catholic Theological Society of America 13: $139-47$. de Liguori, Alphonsus. 1852. Theologia Moralis. Edited by Michael Heilig. Mechlin: P.J. Hanicq, vol. 6.

de Lubac, Henri. 2006. Corpus Mysticum: The Eucharist and the Church in the Middle Ages. Translated by Gemma Simmonds. Edited by Laurence Paul Hemming and Susan Frank Parsons. Notre Dame: University of Notre Dame Press.

Duffy, Eamon. 2005. The Stripping of the Altars: Traditional Religion in England, 1400-1450, 2nd ed. New Haven and London: Yale University Press.

Gambino, Mathew. 2019. Half of Catholics Attending Mass 28 Years Ago no Longer Do, Figures Show. September 5. Available online: CatholicPhilly.com (accessed on 8 March 2021). 
Giussano, John Peter. 1884. The Life of St. Charles Borromeo. London: Burnes and Oates.

Griffen-Foley, Bridget. 2008. Radio Ministries: Religion on Australian Commercial Radio from the 1920s to the 1960s. Journey of Religious History 32: 31-53. [CrossRef]

Hasenfrantz, Robert, ed. 2000. Ancrene Wisse. Kalamazoo: Medieval Institute Publications.

Helland, Christopher. 2000. Religion Online/Online Religion and Virtual communitas. In Religion on the Internet: Research Prospects and Promises. Edited by Jeffery Hadden and Douglas Cowan. London: Jai Press/Elsevier Science, pp. 205-24.

Labenek, Andrew. 2014. The Promise and Problematic of the Virtual Eucharist Mass According to the Roman Catholic Church's Position in 'The Church and the Internet'. Master's thesis, University of Western Ontario, London, ON, Canada. Available online: https:/ / ir.lib.uwo.ca/cgi/viewcontent.cgi?article=3306\&context=etd (accessed on 8 March 2021).

Macy, Gary. 1984. The Theologies of the Eucharist in the Early Scholastic Period. Oxford: Clarendon Press.

Mansi, Giovanni Domenico. 1901-1927. Sacrorum Conciliorum Nova et Amplissima Collectio. Paris: H. Welter.

Mares, Courtney. 2020. Pope Francis Offers this Spiritual Communion Prayer during Coronavirus Pandemic. Catholic News Agency. March 21. Available online: https:/ / www.catholicnewsagency.com/news/pope-francis-offers-this-spiritual-communion-prayerduring-coronavirus-pandemic-53326 (accessed on 8 March 2021).

MacDonald, Ryan. 2020. COVID-19: As Churches Close, Many Turn to 'Mass for Shut-ins' Service. Available online: https: / / atlantic.ctvnews.ca/covid-19-as-churches-close-many-turn-to-mass-for-shut-ins-service-1.4860822 (accessed on 8 March 2021).

Mechtild of Magdeburg. 1998. The Flowing Light of the Godhead. The Classics of Western Spirituality. Translated by Frank Tobin. New York and Mahwah: Paulist Press.

Millard, Egan, and David Paulsen. 2020. Drive Through Communion? Remote Consecration? COVID-19 Sparks Eucharistic Experimentation-And Theological Debate. Episcopal News Service. April 8. Available online: https://www.episcopalnewsservice. org/2020/04/08/drive-thru-communion-remote-consecration-covid-19-sparks-new-eucharistic-concepts-and-theologicalquestions/ (accessed on 8 March 2021).

Mitchell, Nathan. 2009. Eucharist Adoration Revisited. Worship 83: 457-71.

Old St. Patrick's Church. n.d. Available online: https:/ /livestream.com/oldstpats/events/4667723 (accessed on 8 March 2021).

Parish, Helen. 2020. The Absence of Presence and the Presence of Absence: Social Distancing, Sacraments, and the Virtual Religious community during the COVID-19 Pandemic. Religions 11: 276. [CrossRef]

Paul VI. 1965. Mysterium Fidei. Available online: http://www.vatican.va/content/paul-vi/en/encyclicals/documents/hf_p-vi_enc_ 03091965_mysterium.html (accessed on 8 March 2021).

Pine Castle United Methodist Church. n.d. Drive-Thru Communion. Available online: https:/ / pinecastleumc.com/drive-throughcommunion (accessed on 8 March 2021).

Pius X, Pope. 1910. Quam Singulari. Available online: https://www.papalencyclicals.net/pius10/p10quam.htm (accessed on 8 March 2021).

Pius X, Pope. 2015. Catechism of Saint Pius X. London: Aeterna Press.

Pius XII, Pope. 1953. Christus Dominus. Available online: https://www.papalencyclicals.net/pius12/p12chdom.htm (accessed on 8 March 2021).

Pius XII, Pope. 1957. Sacram Communionem. Available online: https://www.papalencyclicals.net/pius12/p12fast.htm (accessed on 8 March 2021).

Pontifical Council for Social Communications. 2002. The Church and Internet. February 22. Available online: http://www.vatican.va/ roman_curia/pontifical_councils/pccs/documents/rc_pc_pccs_doc_20020228_church-internet_en.html\# (accessed on 8 March 2021).

Radbertus, Paschasius. 1969. De corpore et sanguine Domini: Cum appendice Epistola ad Fredugardum. Corpus Christianorum Continuatio Mediaevalis 16. Edited by Peda Paulus. Turnholt: Brepols.

Rahner, Karl. 1953. Die Messe und das Fernsehen. Orientierung 7: 179-83.

Rheingold, Howard. 2000. The Virtual Community, 2nd ed. Cambridge: MIT Press. First Published 1993.

Sacred Congregation for Divine Worship. 1976. Eucharistic Worship outside Mass. In The Rites of the Catholic Church. New York: Pueblo Publishing, vol. 1, pp. 447-512.

Saddleback Church. 2014. Take Communion Online with Us. 24.i. Available online: https://saddleback.com/archive/blog/internetcampus/2014/01/24/take-communion-online-with-us (accessed on 8 March 2021).

Second Vatican Council. 1963. Sacrosanctum Concilium. Available online: https://www.vatican.va/archive/hist_councils/ii_vatican_ council/documents/vat-ii_const_19631204_sacrosanctum-concilium_en.html (accessed on 8 March 2021).

Simons, Thomas Frederick. 2008. The Lay Folks' Mass Book: Or the Manner of Hearing Mass, with Rubrics and Devotions for the People. Whitefish: Kessinger. First Published 1879.

USCCB. 1996. Guidelines for Televised Mass. Available online: https:/ / www.usccb.org/prayer-and-worship/the-mass/frequentlyasked-questions / guidelines-for-televising-the-liturgy (accessed on 8 March 2021).

Wertheim, Margaret. 1999. The Pearly Gates of Cyberspace: A History of Space from Dante to the Internet. London: Virago Press.

Williams, Hattie. 2020. Holy Communion by Mail 'Non Canonical'. Church Times. December 15. Available online: https://www. churchtimes.co.uk/articles/2020/18-december/news/uk/communion-by-mail-pushes-the-envelope-too-far-says-bishop (accessed on 8 March 2021). 
Wright, Robert. n.d. Kéralum, Pierre Yeves. Available online: https://www.omiworld.org/lemma/keralum-pierre-yves / (accessed on 8 March 2021).

Young, Glenn. 2004. Reading and Praying Online: The continuity of Religion Online and Online Religion in Internet Christianity. In Religion Online: Finding Faith on the Internet. Edited by Lorne Dawson and Douglas Cowan. New York: Routledge, pp. 93-106. 